\title{
Discussing the tension between states' right to regulate and foreign investment protection in recent Colombian cases ${ }^{1}$
}

\author{
David Mauricio Guinard HernándeZ²
}

\section{ABSTRACT}

International Investment Agreements are instruments used by states to attract foreign ventures within their borders and obtain favourable treatment to local investors in counterpart nations. States usually compromise a certain degree of sovereignty in this kind of agreements through the inclusion of legal stability agreements, stabilisation clauses, compensation for expropriation, and fair \& equitable treatment provisions. Within the context of this kind of agreements, the legitimate exercise of regulatory powers by states enters in conflict with the protection of foreign investors property rights when it comes to sensitive areas that have a high impact in the public interest, politics and public perception (such as human rights, health, safety, labour standards and the environment). Based on the discussion of two recent paramount cases that involve regulatory actions of the Colombian state and property rights of foreign investors (pharmaceutical IP rights vs public health interests in the first case, consolidated mining titles vs environmental protection in the second case), we identify and criticize the difficulties of defining if a governmental regulatory action is legitimate and non-compensable or if it is subject to compensation as an indirect expropriation, and the high dependence of this matter on the interpretation of arbitral tribunals.

1 Fecha de recepción: 2 de mayo de 2017. Fecha de aprobación: 14 de junio de 2017. Para citar el artículo: Guinard Hernández, D. (2017). Discussing the tension between states' right to regulate and foreign investment protection in recent Colombian cases, en Revista Con-texto, n. ${ }^{\circ} 47$, pp. 89-120. DOI: https://doi.org/10.18601/01236458.n47.05

2 Candidato a Máster en Derecho -LLM- por la Universidad de Melbourne (Australia), Máster en Economía, Regulación y Competencia en los Servicios Públicos por la Universidad de Barcelona (España), Abogado de la Universidad Externado de Colombia. Consultor en temas de derecho público, administrativo, económico, infraestructura, comercial, minero y energético. Email: guinarddavid@gmail.com 
Keywords: International investment agreements - Indirect expropriation - Legitimate exercise of regulatory powers - Foreign investors property rights - Pharmaceutical IP rights - Public health - Consolidated mining.

\section{LA TENSIÓN ENTRE EL DERECHO DE LOS ESTADOS A REGULAR Y LA PROTECCIÓN DE LA INVERSIÓN EXTRANJERA. DISCUSIÓN A PARTIR DEL ANÁLISIS DE CASOS PARADIGMÁTICOS EN COLOMBIA}

\section{RESUMEN}

Los Acuerdos Internacionales de Inversión son instrumentos utilizados por los estados para atraer empresas extranjeras dentro de sus fronteras y obtener un trato favorable para los inversores locales en el exterior. Los Estados suelen comprometer un cierto grado de soberanía en este tipo de instrumentos mediante la inclusión de acuerdos de estabilidad jurídica, cláusulas de estabilización, compensación por expropiación y disposiciones de trato justo y equitativo. En el contexto de este tipo de acuerdos, el ejercicio legítimo de los poderes reguladores por parte de los Estados entra en conflicto con la protección de los derechos de propiedad de los inversionistas extranjeros cuando se trata de áreas sensibles que tienen un alto impacto en el interés general, la política y la percepción pública (como los derechos humanos, la salud, la seguridad, las normas laborales y el medio ambiente). A partir de la discusión de dos casos recientes que involucran acciones regulatorias del Estado colombiano y derechos de propiedad de inversionistas extranjeros (derechos de PI farmacéuticos versus intereses de salud pública en el primer caso, títulos mineros consolidados versus protección ambiental en el segundo caso), realizamos un análisis de las dificultades que conlleva definir si una medida reglamentaria gubernamental es legítima y no indemnizable o si está sujeta a indemnización como expropiación indirecta, así como de la alta dependencia de este asunto en la interpretación de los tribunales arbitrales.

Palabras clave: Acuerdos internacionales de inversión - Expropiación indirecta Ejercicio legítimo de poderes regulatorios - Derechos de propiedad de los inversionistas extranjeros - Derechos de PI farmacéuticos - Salud pública - Titulaciones mineras consolidadas - Protección del medio ambiente.

\section{INTRODUCTION}

Will you deposit your lifetime savings in a precarious bank? Should an investment fund support a project in an unstable country? A major driver for investment decisions is trust. The higher the confidence about the steadiness of the host of a potential investment, the lower the risk related to such investment and therefore, the lower the costs of the venture. Taking into account the nature of most investments, supporting a certain 
venture depends not only on the current conditions of a host country, but also in the anticipations about the future behaviour of its government and its potential effects on investments and financial costs ${ }^{3}$.

From the perspective of project finance, the perception of investors about the steadiness of host countries is measured as political risk. This kind of risk is regarded as 'the possibility that political decisions, events or conditions in a country, including those that might be referred to as social, will affect the business environment such that investors will lose money or have a reduced profit margin' ${ }^{\prime 4}$. The shift in the existing business environment of a country may be the consequence of transfers of power, major swings in the economic model and policy, political or social shocks, or regular policymaking 5 .

The probability of an expropriation is usually the major concern of foreign investors within the assessment of the political risk of a host country. In recent years, some other measures are included in the list of variables to be analysed during the assessment of the political risk of an investment: the exercise of regulatory powers, 'operational restrictions, restrictions on the repatriation of profits, breaches of contracts by the host government, and discriminatory taxation ${ }^{6}$. These measures are examples of what is called indirect - or creeping- expropriation ${ }^{7}$.

In the realm of political risk assessment, there is an ongoing academic discussion about the tension between states' right to regulate and the protection of foreign investments within the framework of international investment agreements ('IIAs'). The discussion is related to the scope and extent of states' compensatory responsibilities towards foreign investors' proprietary rights whenever those rights are affected by a regulatory action ${ }^{8}$.

Within this background, our research will focus on the analysis of governmental regulatory powers as a factor of political risk in the context of international investment law. To contribute to the academic debate, the purpose of this research paper is to discuss the difference between the legitimate exercise of regulatory powers and compensable indirect expropriation in the context of international investment commitments. The discussion will be based on the analysis of two recent cases of potentially expropriating action of the government of the Republic of Colombia that include all the ingredients for a remarkable debate: pharmaceutical IP rights vs public health interests in the first case, consolidated mining rights vs environmental protection in the second case.

The first section of the paper will present the background of states' right to regulate in international investment law and its impact in political risk assessment, particularly

3 All translations are by the author, except otherwise indicated.

PHILliP HARMS, International Investment Political Risk and Growth (New York: Springer, 2000), 72.

4 Lewellyn Howell and Brad Chaddick, 'Models of Political Risk for Foreign Investment and Trade An Assessment of Three Approaches' (1994), 29 Columbia Journal of World Business 70. (emphasis added).

5 Ibid.

6 Ibid., 73.

7 Tullio Treves, Francesco Seatzu, and Seline Trevisanut (eds.), Foreign investment international law and common concerns (Abingdon, Oxon: Routledge, 2014), 219.

8 AIKATERINI TITI, The right to regulate in international investment law (Baden-Baden: Nomos, 2014). 
focused on the tension between the legitimate exercise of regulatory powers (which is not subject to compensation) and indirect expropriation (subject to prompt, adequate and effective compensation), as well as the criteria used to differentiate both circumstances.

The second section of the paper will present the analysis of two paramount recent Colombian cases as an example of the tension between non-compensable exercise of regulatory power and creeping expropriation, taking into account the significance of this kind of decisions for the assessment of political risk in project finance. In this section we will discuss the viability of the claims of the investors against the Colombian state by applying the criteria presented in the first section. Finally, the conclusion section will acknowledge the difficulties that entail the differentiation between legitimate regulatory actions and compensable expropriating measures, and the lessons to be learned from a project finance perspective.

\section{STATES' RIGHT TO REGULATE IN INTERNATIONAL INVESTMENT LAW AND ITS IMPACT IN POLITICAL RISK ASSESSMENT}

The main purpose of international investment agreements ('IIAs') is the promotion and protection of foreign investments in a host nation ${ }^{9}$. IIAs are intended to attract foreign investment to a country and to promote local investments abroad by creating favourable conditions and stable legal regimes for overseas investors. IIAs aim to provide clear and predictable rules for foreign investors by giving them protection, clarity and safety for their investments ${ }^{10}$.

IIAs commonly stipulate international arbitration mechanisms available for foreign investors to pursue claims against the host state for the enforcement of commitments under the agreement. Such provisions remove the dependence on local courts and the burden for investors of getting their home state support ${ }^{11}$.

The aspiration of states when entering in IIAs is to attract foreign investments and at the same time obtain protection for local investors abroad. The price to pay for this purpose is the necessary relinquishment of a certain degree of sovereignty from incumbent states in the form of legal stability agreements, stabilisation clauses, compensation for expropriation, and fair \& equitable treatment stipulations ${ }^{12}$.

It is a common practice in IIAs to include a number of provisions intended to protect foreign investors' property rights from risks that are not inherently related to the commercial activity of the venture (e.g. political risk) ${ }^{13}$. Those provisions involve 'the

9 Ibid., 19.

10 Ministry of Commerce, Industry and Tourism of the Republic of Colombia, Acuerdos Internacionales de Inversión [International Investment Agreements] <http://www.tlc.gov.co/publicaciones.php?id=6126>

11 HenNing Grosse RuSE-KAHN, Protection of intellectual property in international law (Oxford: Oxford University Press, 2016), 151.

12 TITI, above n 6, 19.

13 Treves, SeAtzu and Trevisanut (eds), above n 5, 26. 
prohibition of expropriation without prompt, adequate and effective compensation, and the obligation to provide foreign investors fair and equitable treatment ${ }^{\prime 14}$.

The shared ground of this kind of stipulations is the restraint of the states' right to regulate to favour investors' trust in the reliability and stability of the political environment of the host nation. The problem with states' commitments to reduce political risk is its wide-range and a priori nature, which usually leaves a substantial amount of grey areas where the manoeuvrability of regulatory power is uncertain regarding investors' rights and entitlements ${ }^{15}$.

Restraining regulatory powers as a strategy to reduce political risk within IIAs creates a tension between investors' rights and states' core responsibilities - which are often more important that the promotion of foreign investment-. As pointed out by the specialised literature:

"The pursuit of regulatory interests in nationally sensitive areas, such as essential security and the public order, human rights, sustainable economic growth, environmental protection, social and labour standards, cultural policy and the capacity to respond to situation of economic emergencies, has been circumscribed in order to give way to investment protection, enshrined in an ever-increasing number of international investment agreements" ${ }^{\prime 16}$.

These sensitive areas are usually under the spotlight for their direct relation to public interest, having frequently an extra power of pressure over governments given its impact on politics and public perception. It is currently a matter of discussion the extent to which developing economies are lowering their standards and over-constraining the scope of regulatory powers in IIAs as a strategy to increase foreign investment ${ }^{17}$.

States should be extremely diligent in the assessment of the extent of the commitments they subscribe under IIAs that entail a restriction of their regulatory powers, taking into account that investors are usually entitled to pursue compensation against states for the breach of agreed limitations and for direct and indirect expropriating actions ${ }^{18}$.

Expropriation is commonly recognised as a power retained by host states. Nevertheless, strict rules for the legitimate exercise of that power are set in IIA's to protect investors' property rights and to deter states from recurring to such extreme measure. Those guidelines often include that the expropriation should pursue a public purpose,

14 Ibid.

15 TITI, above n 6, 19.

16 Ibid.

17 Treves, SeAtzu and Trevisanut (eds), above n 5, 26.

18 'The issue directly relates to the very core of the pursuit of common concerns, since drawing the line between indirect expropriation and legitimate regulation implies assessing the state to which a state can legitimately pursue policies of public interest without falling under the obligation to compensate foreign investors'. Ibid., 37. 
that is done over non-discriminatory grounds, following due process of law, and entitling the investor to full compensation ${ }^{19}$.

Expropriation can be classified as direct and indirect. According to specialised international investment law sources:

"An expropriation is direct where the host state takes title to, or possession of, the investment for its own use or for the use of a third party. It is indirect where the investor continues to have title to and possession of the investment, but the value of the investment to the investor has been destroyed as a result of the host state's regulatory activity. Indirect expropriation has also been described as 'regulatory expropriation' (or regulatory taking). Many investment treaties expressly clarify that they also apply to indirect expropriation"20.

The boundary between the legitimate exercise of regulatory powers (which is not subject to compensation) and indirect expropriation (subject to prompt, adequate and effective compensation) is one of the main subjects of discussion in international investment law given its profound effect on investors' economic interests and its high reliance on interpretation ${ }^{21}$.

How to define this boundary? The United States ${ }^{22}$ and Canadian ${ }^{23}$ models of bilateral investment treaties ('BITs') -usually used as reference in the drafting of this kind of agreements- offer us some useful criteria to determine if a host state action should be considered the legitimate exercise of regulatory powers or an indirect expropriation ${ }^{24}$.

According to these models, "the distinction between indirect expropriation and the legitimate exercise of regulatory powers requires a case-by-case, fact-based inquiry that considers, among others, the economic impact, the degree of interference with the investor's reasonable expectations, and the character of the governmental action" ${ }^{\prime 25}$. The models also recommend that a regulatory action of a host nation should not be considered as an indirect expropriation when it is adopted on a non-discriminatory basis and is intended to protect public interest objectives (e.g. health, safety or the environment) ${ }^{26}$.

Another helpful benchmark for the analysis of regulatory measures in the realm of international investment protection is case law from arbitral tribunals that have previously solved investment disputes between states and foreign investors. According to

19 Ibid., 36.

20 Ibid.

21 'Indirect expropriation must be distinguished from the legitimate exercise of state jurisdiction or "pólice powers", which, to the contrary, do not require payment of compensation.' Ibid., 37.

22 Office of the United States Trade Representative, US 2012 Model BIT < https://ustr.gov/sites/default/files/ BIT\%20text\%20for\%20ACIEP\%20Meeting.pdf>

23 ITALAW, Canada 2003 Model BIT <http://www.italaw.com/documents/Canadian2004-FIPA-model-en.pdf>

24 'these criteria are included in all recent US FTAs and BITs and have been argued to reflect customary international law'. GROSSE RuSE-KAHN, above n 9, 189

25 Treves, SeAtzu and Trevisanut (eds), above n 5, 37.

26 Ibid. 
Yannaca-Small ${ }^{27}$, arbitral tribunals use the following criteria to differentiate between the legitimate exercise of regulatory powers and indirect expropriation: (i) the grade of intrusion in the investors' property right ${ }_{i}$ (ii) the drive and background of the regulatory action; (iii) the proportionality of the regulatory action assessed in relation to the government's public policy purpose and the affectation of investor's rights ${ }_{i}$ (iv) the grade of alteration of the legitimate expectations of the investor ${ }^{28}$.

As we can see, the assessment of the potential expropriating nature of a regulatory action is fundamentally based on the analysis of the relevant case, including the appraisal of the factual background of the regulatory decision, the impact on the reasonable economic expectations of the investor, the compliance with fair \& equitable principles, the proportionality and the public interest inspiration of the regulatory measure. The evident problem with these criteria is that they can be highly subjective, extremely difficult to precise, and ultimately contingent upon arbitral definition.

Within this context, in the following section we will apply the discussed criteria by analysing governmental decisions in two different scenarios that have traditionally triggered tensions from the perspective of foreign investors' rights: the protection of pharmaceutical inventions through patents and the restriction of mining activities in environmentally protected ecosystems.

II. THE TENSION BETWEEN STATES' RIGHT TO REGULATE AND FOREIGN INVESTMENT PROTECTION: CASE ANALYSIS

As discussed above, the appropriate way to assess the legitimacy of a regulatory action is by studying the concrete background, facts and motivations of the measures in individual cases. Following the purpose of this research paper, and in order to get a close look of this crucial element of political risk management, in this section we are going to analyse two paramount recent cases of potentially expropriating actions of the government of the Republic of Colombia that mix all the ingredients for a remarkable discussion: pharmaceutical IP rights vs public health interests in the first case, consolidated mining rights vs environmental protection in the second case.

The analysis will be preceded by a brief country overview that gives context about the economy, the international investment status and commitments of Colombia.

\section{A. Country overview}

The Republic of Colombia is a country located in South America. It has a geographically strategic position with shores in both the Caribbean Sea and the Pacific Ocean, and shared borders with Venezuela, Panama, Ecuador, Peru and Brazil. It has a population of

27 Katia YannaCa-SMall, Arbitration under international investment agreements: a guide to key issues (Oxford: OuP, 2010), 460.

28 Treves, SeAtzu and Trevisanut (eds), above n 5, 38. 
around 49 million people (most of them Spanish speakers) and a GDP of us \$293 billions (us $\$ 6083.5$ per capita) ${ }^{29}$.

Colombia is considered a developing Country. Its economic potential has been constrained by a long-run internal armed conflict with FARC guerrillas and other violent armed groups. Economic growth in Colombia has also been constrained by corruption, infrastructure underdevelopment and poor industrialisation ${ }^{30}$.

The Colombian economy has shown signs of stability and moderate growth in the last few years. This recent improvement is attributed to high commodities prices, regulatory enhancements, efficient macroeconomic and fiscal management and a strong investment attraction policy ${ }^{31}$. There are high expectations about the strengthening of the Colombian economy in the following years given the closure and implementation of the peace agreement with FARC guerrillas, and the robust government strategy for the development of infrastructure projects ${ }^{32}$.

Colombia has a well-established commitment to free trade and foreign investment, promoted within the framework of social market economy established in the Colombian Constitution of 1991. Such framework comprises broad economic freedoms, including the freedoms of economic activity, private initiative, competition, and enterprise development ${ }^{33}$.

According to Trading Economics:

"Foreign Direct Investment in Colombia increased by 1965.89 USD Million in the third quarter of 2016. Foreign Direct Investment in Colombia averaged 1929.35 USD Million from 1996 until 2016, reaching an all-time high of 6776.22 USD Million in the fourth quarter of 2005 and a record low of 197.17 USD Million in the third quarter of $2002^{\prime 34}$.

The Country has signed several free trade agreements with other nations around the world. According to the Colombian Ministry of Commerce, Industry and Tourism ('MCIT'), the Country has effective free trade agreements with Mexico, El Salvador, Guatemala, Honduras, Chile, Canada, United States, Cuba, Nicaragua, the European Union, MERCosur, CARICOM, South Korea and Costa Rica. The Country also has ongoing negotiations for free trade agreements with Turkey, Japan, Israel and Panama ${ }^{35}$, and is part of regional agreements that include free trade commitments, such as the Andean Community of

29 Klaus SchWab and Xavier Sala-i-Martín, 'The Global Competitiveness Report 2016-2017' (Report, World Economic Forum, 2016), 149.

30 The World Bank, Overview (26 September 2016) The World Bank <http://www.worldbank.org/en/country/colombia/overview\#1>

31 Ibid

32 Ibid

33 Constitución Política de Colombia 1991 [Colombian Constitution 1991] art 334.

34 Trading Economics, Colombia Foreign Direct Investment < http://www.tradingeconomics.com/colombia/ foreign-direct-investment>

35 Ministry of Commerce, Industry and Tourism of the Republic of Colombia, Acuerdos Comerciales y de Inversión [Commercial and Investment Agreements] <http://www.tlc.gov.co/index.php> 
Nations ('CAN') including Bolivia, Colombia, Peru and Ecuador, as well as the Pacific Alliance which integrates Mexico, Colombia, Peru and Chile ${ }^{36}$.

Bilateral investment treaties ('BIT's) are also in the Colombian agenda of international policy. Up to this day, Colombia has effective BIT's with Mexico, Chile, Guatemala, El Salvador, Honduras, EFTA (Swiss Federation-Liechtenstein-Norway-Iceland), Canada, United States, Spain, Japan, Peru, China, India and the United Kingdom ${ }^{37}$. The Country has ongoing negotiations for BIT's with the European Union, South Korea, Singapore, France and Turkey ${ }^{38}$.

\section{B. Case 1: Price control over Glivec ${ }^{\mathrm{TM}}$}

\section{Foreword}

As discussed in the previous section, the tension between the legitimate exercise of regulatory actions of a host government and compensable indirect expropriation of foreign investors' property rights gets intensified when it comes to nationally sensitive matters that involve public interest, such as human rights, labour standards or environmental compliance. Public health -particularly the access to and affordability of medicines- has traditionally been a ground of pressure for the exercise of regulatory powers ${ }^{39}$.

The principal counterpart of states regarding public health regulations is the pharmaceutical industry. This knowledge-based technology-intensive industry depends on a fundamental service provided by states: the recognition and enforcement of intellectual property $\left({ }^{\prime} \mathrm{IP}^{\prime}\right)$ rights. The business model of the pharmaceutical industry is founded on the legal monopoly of new medicines through the consolidation of patent rights ${ }^{40} \mathrm{~Pa}$ tents and IP rights are commonly included as protected investments in IIAs: "today, the model BITs of most countries address IP rights." 41

The outstanding amount of research and testing that is required in the development of a new medicine is financed by pharmaceutical companies based on the expectation to commercialise the medicine in the future under exclusive rights derived from patents.

36 Ministry of Commerce, Industry and Tourism of the Republic of Colombia, Acuerdos Vigentes [Effective Agreements] <http://www.tlc.gov.co/publicaciones.php?id=5398>

37 Ministry of Commerce, Industry and Tourism of the Republic of Colombia, Acuerdos Internacionales de Inversión Vigentes [Effective International Investment Agreements] <http://www.tlc.gov.co/publicaciones. php?id=6420>

38 Ministry of Commerce, Industry and Tourism of the Republic of Colombia, Acuerdos Internacionales de Inversión Suscritos [Subscribed International Investment Agreements] <http://www.tlc.gov.co/publicaciones. php?id=6421>

39 'The debate on patent protection for pharmaceutical products and access to life-saving drugs is probably the most commonly known example of international IP rules impacting on common societal interests (public health) as well as individual human rights (right to health).' Grosse Ruse-Kahn, above n 9, 10.

40 PricewaterhouseCoopers, Pharma 2020: Challenging business models Wbich path will you take? (Report, PricewaterhouseCoopers, 2009)

41 Grosse RuSE-KaHN, above n 9, 155. 
Innovation in the pharmaceutical industry relies directly on the existence and enforceability of patent rights around the globe ${ }^{42}$.

On the other side of the coin we have health public policy and patient rights. An important part of health public policy in the XXI century is focused on preventive action and effective treatment of disease. These public policy goals can only be accomplished with an exponential increase of access to up-to-date medications to the entire population -especially those with a higher risk of disease $-{ }^{43}$.

The treatment of potentially lethal and complex diseases raises questions in the realm of human rights. The medications to treat this kind of diseases are usually scarce and expensive. Patients usually cannot afford such treatments on their own. The financial support of governments and health insurers gets more restrained given the rising number of patients, high costs and limited funds.

The discussion is set within a background of two reasonable interests that are in conflict: on one hand, the genuine interest of pharmaceutical companies in protecting their IP rights through patents, and to set medicine prices that allow them to finance research and further developments; and on the other hand, the genuine interest of patients and governments in increasing the accessibility and affordability of medications, and therefore reduce mortality and increase life quality.

When this conflict of divergent interests rises within the context of international investment law it embodies an emblematic example of the tension between the legitimate exercise of regulatory powers and compensable indirect expropriation. States will attempt to get reasonable prices of medicines (e.g. with price controls or compulsory licenses) while foreign investors (pharmaceutical companies) will defend their patent property rights, their exclusivity in markets and their prices.

Within this background, in the lines below we are going to discuss the recent decision of the Colombian government to impose a price control scheme over the medicine Glivec $^{\mathrm{TM}}$ patented by the Swiss multinational pharmaceutical company Novartis.

\section{Context}

Imatinib is a medication used to treat chronic myelogenous leukaemia and other types of cancer. The medication is included in the World Health Organization ('WHO') model list of essential medicines ${ }^{44}$. It is also included in the Colombian Mandatory Health Plan.

Imatinib was formerly commercialised under competitive prices as a generic medicine by a number of incumbents in Colombia until 2012, when the Swiss multinational

42 PricewaterhouseCoopers, above n 38.

43 World Health Organization, Who we are what we do <http://www.who.int/about/en/>

44 World Health Organization, wHO Model Lists of Essential Medicines < http://www.who.int/medicines/publications/essentialmedicines/en/> 
pharmaceutical company Novartis got from the Colombian government the patent over the medicine under the trademark Glivec ${ }^{\mathrm{TM}} 45$.

In 2014, a procedure for declaring the existence of reasons of public interest over the medicine imatinib started as a consequence of a special request filed by the Colombian representative of the NGO Health Action International (' $\left.\mathrm{HAI}^{\prime}\right)$-along with some other local activist organisations-.

The main argument of the request was high prices of Glivec ${ }^{\mathrm{TM}}$ in the Colombian market. According to the petitioners, prices of Glivec ${ }^{\mathrm{TM}}$ were fixed by Novartis following a monopoly reasoning instead of competitive and industrial criteria. The situation was aggravated with the exclusion of generic forms of imatinib as a consequence of the patent granted in 2012. For the petitioners, the impact of this monopolistic circumstance over the financial stability of the Colombian public health system would be huge, consequently affecting all the population ${ }^{46}$.

The procedure first started as a necessary step towards compulsory licensing of Glivec $^{\mathrm{TM}}$. According to the international treaties subscribed by the Country, prior to a decision of compulsory licencing of a privately owned patent, the government must analyse the circumstances to consider the existence of reasons of public interest over the relevant medicine.

As part of the procedure, the Colombian Ministry of Health and Social Protection ('the Ministry') tried to enter into direct negotiations with Novartis seeking a voluntary reduction of the local price of $\mathrm{Glivec}^{\mathrm{TM}}$, taking into account that the market analysis conducted by the Ministry showed that the price of the medicine was relatively high compared with international prices and potential local competitors (198\% higher $)^{47}$. Notwithstanding the invitation from the Colombian government, Novartis decided not to negotiate the price of Glivec ${ }^{\mathrm{TM}}$ arguing that it was inconvenient to enter into a price negotiation $^{48}$.

After long discussions and arguments between the Colombian government and Novartis, in June 2016 the Ministry decided to declare the existence of reasons of public interest over the medicine imatinib. As a consequence of this decision, the Colombian government proceeded to impose a price control regime over Glivec ${ }^{\mathrm{TM}}$ (instead of a compulsory licence regime). of reasons of public interest over the medicine imatinib < https://www.minsalud.gov.co/sites/rid/Lists/BibliotecaDigital/RIDE/VS/MET/Solicitud-de-una-declaracion-en-el-acceso-al-medicamento-IMATINIB.pdf>

47 Ministry of Health and Social Protection of the Republic of Colombia, Análisis de mercado del imatinib en colombia y proyección de impacto presupuestal de la declaratoria de razones de interés público [Market analysis of imatinib in Colombia and projection of the budgetary impact of the declaration of reasons of public interest] < https://www.minsalud.gov.co/salud/MT/Paginas/medicamentos-propiedad-intelectual.aspx> pdf $>$ 
Regulatory action of the Colombian state

According to article 49 of the Colombian Constitution, health attention and environmental well-being are public services under the responsibility of the state, which shall guarantee the access to health promotion, protection and recovery services to all the people.

To accomplish such responsibility, the state is constitutionally entitled of directing the provision of health services following the principles of efficiency, universality and solidarity ${ }^{49}$. Under similar reasoning, article 366 of the Colombian Constitution establishes general wellbeing and the enhancement of people's life quality as social goals of the state, instituting as a fundamental objective the solution of unsatisfied health, education, environmental and water supply necessities ${ }^{50}$.

In accordance with those guidelines, Law 1751 of 2015 established health as an autonomous human right of non-renounceable nature. It also provides that the health system -under state direction- shall pursue the most effective use of the available economic resources, services and technologies in order to guarantee the human right to health of all the population ${ }^{51}$.

In Resolution 2475 of 14 June 2016, the Ministry explains the reasoning behind the decision of declaring the existence of reasons of public interest related to the medicine imatinib pursuing the implementation of a regime of direct control of prices over the medicine Glivec ${ }^{\mathrm{TM}}$, commercialised by Novartis.

Based on the constitutional and legal grounds explained above, the Ministry presents the following arguments to support its decision:

(i) The government's pharmaceutical public policy ${ }^{52}$ targets a permanent reduction of medicines prices as a strategy to promote the sustainability of the health system.

(ii) The market analysis conducted by the Technical Committee for the Declaration of Reasons of Public Interest of the Ministry ('the Committee') showed that the price of Glivec $^{\mathrm{TM}}$ was relatively higher compared with international prices and potential local competitors (198\% higher $)^{53}$.

(iii) Other studies conducted by the Ministry showed that Glivec ${ }^{\text {TM }}$ had a monopoly status in the market, given the fact that there are not adequate therapeutical substitutes that can work as a front line treatment as Glivec ${ }^{\mathrm{TM}}$.

(iv) The public funds used by the government to finance medications ${ }^{54}$ are scarce and have a paramount public importance. A price control scheme that simulates a competitive price can help to save public funds while respecting private party rights. 
It is important to highlight that, even though the Ministry had the necessary arguments and followed the proper procedure -the declaration of reasons of public interest- to impose a compulsory licencing scheme over Glivec ${ }^{\mathrm{TM}}$, it opted not to do so.

Being conscious of the intensity of such a decision, the Ministry considered that the implementation of a regime of direct control of prices based on the simulation of competition was a reasonable and proportional alternative to compulsory licencing that allowed an efficient management of public funds while respecting the IP rights of Novartis ${ }^{55}$.

Following the decision of the Ministry, by December 2016 the Colombian National Commission for Medications and Medical Devices Pricing determined a maximum price of Glivec ${ }^{\mathrm{TM}}$ following a novel methodology that simulates competitive conditions between the patented molecule and its generic counterparts. The decision of the Colombian government represents an effective $44 \%$ reduction from the original price charged for Glivec $^{\mathrm{TM}}$ by Novartis in the Country ${ }^{56}$.

The company has publicly argued that there was no legitimate argument for the Colombian government to declare public interest over imatinib, neither to fix a maximum price for their patented medicine Glivec ${ }^{\mathrm{TM}}$

According to Novartis' statement, the declaration of reasons of public interest was arbitrary because: (i) the company has never held the monopoly of the molecule imatinib in the Country; (ii) the existence of a legal patent over Glivec ${ }^{\mathrm{TM}}$ does not affect the access of patients to the treatment ${ }_{i}$ (iii) the Colombian government has been controlling the price of Glivec ${ }^{\mathrm{TM}}$ since $2011_{\text {; }}$ (iv) there are no real threats of a supply shortage of the medicine, and finally; $(\mathrm{v})$ declaring the existence of reasons of public interest and setting a price cap over Glivec ${ }^{\mathrm{TM}}$ does not solve the structural financial problems of the Colombian public health system ${ }^{57}$.

Novartis has also publicly rejected the unprecedented decision of the Colombian government arguing that it may be against the provisions of the BIT signed between Colombia and the Swiss Federation ${ }^{58}$. There are also reports of approaches from agents of the United States Senate to the Colombian Embassy in Washington trying to persuade the Colombian government to withdraw its intentions to impose price controls or compulsory licencing over Glivec ${ }^{\mathrm{TM} 59}$.

56 Ministry of Health and Social Protection of the Republic of Colombia, El Gobierno fija el precio del Glivec en \$206 por miligramo [Government fixes the price of Glivec at COP\$206 per milligram] <https://www. minsalud.gov.co/Paginas/El-Gobierno-fija-el-precio-del-Glivec-en-\$-206-por-miligramo.aspx>

57 Novartis, above $\mathrm{n} 42$.

58 Ibid.

59 El Espectador, Las presiones de EE.UU. para que Colombia no regule el precio del imatinib [The pressures of the United States to prevent the Colombian price regulation of imatinib] (10 May 2016) <http://www.elespectador. com/noticias/salud/presiones-de-eeuu-colombia-no-regule-el-precio-del-imat-articulo-631535> 


\section{Viability of the investor's potential claim}

Was the price control over Glivec ${ }^{\mathrm{TM}}$ in Colombia a legitimate exercise of regulatory power by the Colombian government, a disguised compulsory licensing measure or an indirect expropriation?

Price control of Glivec ${ }^{\mathrm{TM}}$ in Colombia is not the first case of a conflict between a multinational company and a state for the protection of IP rights over medicines under IIA's. In 2007 the pharmaceutical giant Merck publicly attacked the actions of the Brazilian government towards the imposition of a compulsory licence over the medicine efavirenz (an antiretroviral drug used to treat AIDS) patented by the company under the trademark Stocrin ${ }^{\mathrm{TM}}$. Similar critiques have followed compulsory licensing decisions in India, Ecuador, Thailand and Malaysia ${ }^{60}$.

Other kinds of state actions related to IP rights have been under the spotlight for its potential expropriating nature. In the recent and well-known plain packaging cases of the multinational tobacco company Philipp Morris against the Uruguayan and Australian governments, the Company has argued that plain packaging restrictions are expropriating since they dispossess the Company of the rightful use of its intellectual property and extinguishes the value of the brands without fair and equitable compensation ${ }^{61}$. These cases are a good example of the difficulties of determining the frontier between legitimate regulatory actions and compensable indirect expropriation.

How to define then if a regulatory measure restricting IP rights -like the one executed by the Colombian government controlling Glivec ${ }^{\mathrm{TM}}$ prices- is expropriating or not (and therefore subject to compensation)? The problem seems to reside in the indeterminacy and lack of clarity of the concept indirect expropriation, which opens the door for investors "to challenge host states measures affecting the commercial exploitation of their IP protected goods and services"

The viability of the potential claim of Novartis against the Colombian state under an international investment law scheme depends on the question of whether a government regulation intended to increase access to medicines for the local population (like compulsory licences or price controls) is a legitimate action subject to the provisions of free trade agreements and IIA's related to IP rights, its exceptions and flexibilities ${ }^{63}$. According to the specialised literature, "the interface between IP protection and expropriation is the topic which has so far received most attention amongst the substantive standards of treatment an investor can expect under a IIA for his IP rights" 64 .

There will only be a case against the Colombian state if the declaration of reasons of public interest related to the medicine imatinib that derived in price limitations over

60 Grosse RuSE-KAHN, above n 9, 187.

61 Ibid., 188.

62 Ibid., 189.

63 Ibid., 187.

64 Ibid. 
Glivec $^{\mathrm{TM}}$ can be considered a compensable compulsory licensing decision or an indirect expropriating action under applicable Colombian-Swiss agreements.

For solving the issue, there is a crucial instrument that must be taken into account in terms of IP rights in the international investment law context: the Agreement on TradeRelated Aspects of Intellectual Property Rights ('TRIPS') administered by the World Trade Organization ('WTO') ${ }^{65}$. This agreement "establishes minimum levels of protection that each government has to give to the intellectual property of fellow WTO members" ${ }^{\prime \prime 6}$ based on the principles of non-discrimination, national treatment, most favoured nation treatment and fair and equitable treatment ${ }^{67}$.

The TRIPS agreement is highly relevant to the discussion of the tension between pharmaceutical IP rights and the extent of governmental regulations. The agreement provides a scheme of exceptions and flexibilities to IP rights protection in order to defend "public health and nutrition, and to promote the public interest in sectors of vital importance to their socio-economic and technological development" ${ }^{\prime \prime}$. The agreement also provides that states may undertake suitable measures "to prevent the abuse of intellectual property rights by right holders or the resort to practices which unreasonably restrain trade or adversely affect the international transfer of technology"69.

Part of this regime of exceptions and flexibilities is compulsory licensing of medicines as a flexibility of patent protection. Article 31 of the TRIPS agreement allows member states to legitimately issue compulsory licenses over pharmaceutical patented rights following broad principles of: (i) previous negotiation of voluntary licence with the patent holder on reasonable commercial terms; (ii) limited scope and time duration of the compulsory licence; (iii) non-exclusion of the patent holder of his right to produce $_{;}$(iv) the payment of adequate remuneration to the patent holder; (v) submission to judicial review of the compulsory licensing decision and the terms of the adequate remuneration to the patent holder ${ }^{70}$.

We should remind that, despite following the procedure towards the imposition of a compulsory licence over Glivec ${ }^{\mathrm{TM}}$, the decision of the Colombian government was limited to a declaration of public interest reasons over the medication imatinib and the consequential imposition of a price cap over Glivec ${ }^{\mathrm{TM}}$, without breaking Novartis patent rights in terms of compulsory licensing (which would have entail adequate remuneration under the TRIPS agreement).

Since the regulatory action of the Colombian government was not a compulsory license over Glivec ${ }^{\mathrm{TM}}$, the concrete case of a potential claim of Novartis should be fur-

Agreement on Trade-Related Aspects of Intellectual Property Rights ('TRIPS'), Annex 1C of the World Trade Agreement (Marrakesh, 15 April 1994, 1869 UNTS 299).

66 World Trade Organization, Intellectual property: protection and enforcement < https://www.wto.org/english/ thewto_e/whatis_e/tif_e/agrm7_e.htm>

67 TRIPS

68 TRIPS, art. 8.

69 Ibid.

70 TRIPS, art. 31 
therly analysed under the provisions related to the protection of IP rights contained in Chapter 6 of the Free Trade Agreement between the Republic of Colombia and the EFTA States (including the Swiss Confederation), which establishes that "the Parties reaffirm their existing rights and obligations, including the right to apply the exceptions and to make use of the flexibilities, under the TRIPS Agreement, and any other multilateral agreement related to intellectual property ${ }^{\prime \prime 71}$.

In development of such recognition, the agreement determines that parties may take appropriate measures "to prevent the abuse of intellectual property rights by right holders or the resort to practices which unreasonably restrain trade or adversely affect the international transfer of technology ${ }^{\prime \prime 7}$, in accordance with paragraph 2 of Article 8 of the TRIPS Agreement.

The Colombia-EFTA agreement also provides that parties may "adopt measures necessary to protect public health and nutrition, and to promote the public interest in sectors of vital importance to their socio-economic and technological development ${ }^{173}$, in harmony with paragraph 1 Article 8 of the TRIPS Agreement. According to the specialised doctrine:

"These safeguards for compulsory licenses and often other forms of limitations to IP rights seem to offer sufficient legal security for the host state that it may continue to rely on flexibilities in TRIPS and other IP treaties. At the same time, these safeguard clauses offer investors predictability that the more specific international IP standards will in part govern the question of (indirect) expropriation under investment protection" ${ }^{\prime \prime 7}$

Based on the safeguard clauses in the Colombia-EFTA free trade agreement and the applicable flexibilities provided by the TRIPS agreement, we can argue that the price control over Glivec ${ }^{\mathrm{TM}}$ imposed by the Colombian government can be considered a necessary measure to protect public health and therefore promote the public interest. Consequently, Novartis is not entitled to any kind of compensation under a compulsory licensing scheme, neither on the grounds of indirect expropriation.

Our conclusion can be complemented with a benchmark analysis of the expropriating potential of the Colombian government action. As announced in the first section of this paper, the United States and the Canadian models of BITs, as well as the principles developed by arbitral tribunals in investment disputes, are commonly used benchmarks for evaluating the expropriating nature of a government's action. These criteria can be summarized as: (i) The grade of intrusion in the investors' property right; (ii) The economic impact of the regulatory action; (iii) The magnitude of the interference of the regulatory action with the reasonable expectations of the foreign investor; (iv) The

74 Grosse RuSE-KaHN, above n 9, 187. 
nature of the regulatory action -including its drive and background-and $(\mathrm{v})$ The proportionality of the regulatory action.

Applying these criteria to the price control over Glivec ${ }^{\mathrm{TM}}$ allows us to conclude that:

(i) The grade of the intrusion in Novartis property right was reduced in terms of the economic impact of the measure on the value of the investment ${ }^{75}$. The degree to which the price control affected the price set by Novartis may be considered high ( $44 \%$ reduction from the original price), but seems reasonable taking into account that the original price was $198 \%$ higher compared with international prices and potential local competitors.

(ii) From the perspective of the grade of interference of the regulatory action with the reasonable expectations of Novartis, is crucial to take into account that "the grant of an IP right as such therefore does not provide for any legitimate expectations that those rights are not subject to any of the commonly used limits to IP protection"76.

The reasonable expectations of Novartis should have been that Colombia would act within the exceptions and flexibilities to IP rights protection established in both the Colombia-EFTA and TRIPS agreements, which the Country effectively did by setting a price control over Glivec ${ }^{\mathrm{TM}}$ as a necessary measure to protect public health and therefore promote the public interest.

(iii) Finally, from the point of view of the nature and proportionality of the government action, the customary international law doctrine of police powers argues that a "state does not incur in responsibility for the legitimate and bona fide exercise of sovereign police powers-subject to specific commitments and an analysis of proportionality or reasonableness"77. According to the cited international investment law literature, "any public health motivated measures such as compulsory licenses for patented drugs or plain tobacco packaging will thus generally benefit from this doctrine ${ }^{\prime \prime 7}$.

The reasonableness of the price control imposed by the Colombian government was based on the public policy target of the government towards a permanent reduction of medicines prices, on the evidenced high price of Glivec ${ }^{\mathrm{TM}}$ in the Colombian market compared with international prices and potential local competitors, the lack of adequate therapeutical substitutes which gave Glivec ${ }^{\mathrm{TM}}$ a monopoly status, and the necessity to guarantee the sustainability of the public health system through competitive medicine prices. Its proportionality was based on the fact that the price cap was defined following a novel methodology that simulates competitive conditions between the patented molecule and its generic counterparts. circumstances -such as the terms of the compulsory license; the amount and price of parallel imported drugs; and the degree to which price controls affect the price set by the patent holder'. Ibid., 190. Ibid., 191.

77 Ibid.

78 Ibid. 
We can accordingly conclude that there is a reduced viability of a potential claim of Novartis against the Republic of Colombia for the declaration of reasons of public interest related to the medicine imatinib that derived in price limitations on $\mathrm{Glivec}^{\mathrm{TM}}$. The regulatory action of the Colombian government was neither a compensable compulsory licensing nor a compensable indirect expropriating measure.

Our conclusion is endorsed by the specialised literature which states that:

"As long as their character and underlying rationale [of the regulatory actions] consists of good faith public welfare goals such as facilitating access to medicines and they are non-discriminatory and proportional in nature, investors are unlikely to succeed with claims of indirect expropriation" ${ }^{\prime 79}$.

\section{Case 2: Restriction of mining activities in moorland ecosystems}

\section{Foreword}

Environmental compliance and sustainable development are also highly sensitive matters when it comes to the tension between legitimate regulatory actions of host governments and compensable indirect expropriation of foreign investors' property rights. The intensification of this tension may be attributed to the increment of environmental awareness and climate change mitigation commitments.

It would be fair to affirm that the approach of states towards environmental protection and sustainable development has been strengthening in the last 20 years ${ }^{80}$, despite the recent reluctance of some governments to acknowledge the existence of climate change and its direct relation to human activities ${ }^{81}$.

Ever since the signature of the Kyoto protocol in 1997, the scientific community and environmental activists have been pushing for stronger states' commitments towards the reduction of emissions for mitigating climate change. The recent Paris Agreement "to combat climate change and to accelerate and intensify the actions and investments needed for a sustainable low carbon future ${ }^{\prime \prime 22}$, and the outstanding follow-up meeting held in Marrakesh in November 2016 which "successfully demonstrated to the world that the implementation of the Paris Agreement is underway and the constructive spirit of multilateral cooperation on climate change continues" ${ }^{\prime \prime}$, are good examples of the

79 Ibid.

80 United Nations Framework Convention on Climate Change, Kyoto Protocol <http://unfccc.int/kyoto_protocol/items/2830.php>

81 MAZIN SIDAHMED, Climate change denial in the Trump cabinet: where do bis nominees stand? The Guardian (16 December 2016) <https://www.theguardian.com/environment/2016/dec/15/trump-cabinet-climatechange-deniers $>$

82 United Nations Framework Convention on Climate Change, Summary of the Paris Agreement <http://bigpicture.unfccc.int/\#content-the-paris-agreemen>

83 United Nations Framework Convention on Climate Change, Marrakech Climate Change Conference - November 
substantial joined commitments from most of the world's nations towards the mitigation of climate change through the restriction of environmentally harmful human activities.

This trend of state actions is not only noticeable in the fight against climate change. State's environmental regulations and restrictions are becoming stricter thanks to the availability of more accurate scientific information about the effects of human activities in the environment, the increment of public awareness about environmental conservation and the pressure over governments to take positive actions towards its protection.

The public attention is set on the way governments manage the exploitation of natural resources and the environmental accountability of private companies. Public endorsement of these issues has taken environmental regulations to the top places in political agendas.

The difficulty that surfaces from the perspective of international investment law is the ponderation between foreign investors' property rights and governments' environmental regulations (which are getting harsher every day). Many states' commitments under IIA's were subscribed before the upsurging trend of environmental awareness, back in times when light regulations were a common strategy to attract foreign investments (particularly in developing countries).

In the present days, compliance with international environmental commitments and higher public pressures are making governments to strengthen green regulations, increasing the spectrum of possible conflicts with consolidated property rights of foreign investors subject to protection under IIA's.

The fundamental question that arises from this issue is how to determine if a foreign investor is entitled to compensation following an environmental regulatory action of a host government that entails some sort of deprivation of its property rights? Does the paramount value of environmental protection represent a reasonable and proportional justification for the exercise of regulatory powers without compensation?

Within this background, in the lines below we are going to discuss the recent decision of the Colombian government to restrict the allowed area for the exploitation of a gold-silver reserve by the Canadian company ECO ORO MINERALS CORP, which was taken following a decision of the Colombian Constitutional Court to forbid all mining and hydrocarbons activities in moorland ecosystems.

\section{Context}

ECO ORO MINERALS CORP (TSX: 'EOM') is a Canadian publicly-traded precious metals exploration and mining development company. It arrived to Colombia in 1994 with the purpose to undertake the exploration and exploitation of gold-silver in a project called Angostura located near a moorland ecosystem known as Santurban (north-eastern Colombia).

According to the information provided by the Company: 
"Eco Oro was one of the first foreign mining companies to invest in the country's gold mining sector. Since the mid-1990s, the Company has invested over us $\$ 250$ million to develop the Angostura mining project (the "Project") by completing more than 360,000 meters of drilling and 3,000 meters of underground development. As a result of these investments, Eco Oro declared resources for the Angostura deposit where none existed before, and doubled those resources between 1999 and 2015. The deposit is now one of the largest in Colombia" ${ }^{14}$

The company (formerly known as GREYSTAR) has legally developed mining exploration activities in the area as the holder of the mining title contained in the concession contract 3452 signed with the Colombian government in 2007, which had an original duration of 20 years. The investments made by the company were supported by its confidence in the international investment policy of the Colombian state, as well as the government's support to the project -once considered of national interest-.

The project was partially funded by the International Financial Corporation ('IFC') -member of The World Bank group-, which invested USD $\$ 9.6$ million in equity $(12.5 \%$ of the company's shares) in 2009[85], "to fund completion of a bankable feasibility study (BFS), an environmental and social impact assessment (ESIA) and other ground works to prepare for the construction of an open-pit mine"

Roughly 50 percent of the area of the concession contract 3452 was believed to be part of a moorland ecosystem ${ }^{87}$. Moorlands (locally known as Páramos) are ecosystems that capture water from fog and supply it to lowlands ${ }^{88}$ : "healthy páramos also capture large amounts of carbon, mitigating climate change, and provide refuge for hundreds of threatened species, including the iconic spectacled bear ${ }^{\prime \prime} 89$. Moorlands are subject to high levels of protective measures given their importance for water supply, endemic animal and vegetal species and natural weather regulation ${ }^{90}$.

The moorland of Santurban (where the Angostura gold-silver deposit is located) is an alpine tundra ecosystem considered a "biological corridor characterised by herbaceous vegetation that ranges from 3,000 to 3,800 metres $(9,842$ to 12,467 feet) above

84 Eco Oro Minerals Corp, Eco Oro files Request for Arbitration against Colombia (09 December 2016) <http:// www.eco-oro.com/s/NewsReleases.asp?ReportID=774271\&_Type=News-Releases\&_Title=Eco-Orofiles-Request-for-Arbitration-against-Colombia>

85 Center for International Environmental Law ('CIEL'), World Bank divests from Eco Oro Minerals and its mining project in the Colombian Páramos (21 December 2016) <http://www.ciel.org/news/9504/>

86 Office of the Compliance Advisor Ombudsman for the International Finance Corporation \& Multilateral Investment Guarantee Agency Members of the World Bank Group ('CAO'), CAO Investigation of IFC Investment in: Eco Oro Minerals Corporation Limited (\#27961) <http://www.cao-ombudsman.org/cases/document-links/ documents/CAOComplianceInvestigationReportonIFCinvestmentinEcoOroMinerals-English.pdf>

87 Mining Journal, Eco Oro requests arbitration (15 December 2016) <http://www.mining-journal.com/world/ centralsouth-america/eco-oro-requests-arbitration/>

88 Interamerican Association for Environmental Defense ('AIDA'), Protecting the Santurban Páramo from Angostura Mining Project <http://www.aida-americas.org/protecting_the_santurban_paramo_from_angostura_project>

89 Ibid.

90 Ibid. 
sea level. It provides water to over 2.2 million people that inhabit the metropolitan areas of Bucaramanga and Cucuta, and 21 other municipalities in Santander and Norte de Santander" ${ }^{\prime \prime 1}$.

In 2009 ECO ORO applied for an environmental license to develop an open-pit gold and silver mine within the area of concession contract 3452. The National Authority of Environmental Licences (a governmental agency subordinated to the Colombian Ministry of Environment and Sustainable Development) rejected the license application in 2010 arguing lack of compliance with recent modifications of the Colombian Mining Code, as well as the prohibition to undertake mining activities in moorland ecosystems in Colombia ${ }^{92}$.

Up until 2014 there was no official delimitation of the moorland of Santurban for environmental purposes. The official delimitation of the protected moorland and the definition of the allowances for natural resources exploitation purposes took place in December 2014. With this decision, the Colombian government announced that existing mining titles with effective licences for the exploration and exploitation of natural resources were going to be allowed and respected up until the expiration of the relevant licences ${ }^{93}$.

\section{Judicial intervention and regulatory action of the Colombian state}

In decision C-035 released 8 February 2016, the Colombian Constitutional Court ruled the partial invalidation of article 173 of Law 1753 of 2015 which contained regulations related to mining exploration and exploitation activities in moorland ecosystems ${ }^{94}$.

Article 173 of Law 1753 of 2015 provided a general rule of exclusion of agricultural activities, mineral and hydrocarbons exploration and exploitation activities, as well as the construction of hydrocarbons refineries in areas officially defined as moorland ecosystems ${ }^{95}$.

Paragraph 1 of the article provided an exception for those titles granted before a given date if they already had an environmental licence, being aware of the existence of previously granted mining licences over areas that could potentially be part of moorland ecosystems. In those cases, exploration and exploitation activities could continue

91 Environmental Justice Organisations Liabilities and Trade ('EJOLT'), The Angostura Mining Project in the Paramo of Santurban, Colombia (25 February 2013) <http://www.ejolt.org/wordpress/wp-content/uploads/2013/02/ FS_002_Angostura.pdf>

92 CAO, above n 84.

93 El Tiempo, Minambiente delimita 98.954 bectáreas, el $76 \%$ del páramo de Santurbán [The Ministry of Environment delimitates 98.954 hectares, $76 \%$ of the Santurban moorland] (19 December 2014) <http://www. eltiempo.com/colombia/otras-ciudades/delimitacion-del-paramo-de-santurban/14996735>

94 Corte Constitucional [Colombian Constitutional Court], C-035, 8 February 2016.

95 Ley 1751 de 2015 [Law 1751 of 2015], art. 173. 
during its original duration under a strict supervision of the environmental authority and without right of term extension ${ }^{96}$.

The Court considered that the exception included in paragraph 1 was unconstitutional given the fragility, sensibility and vulnerability of moorland ecosystems and the special protection that they have within the Colombian constitutional framework. Therefore, the exception was excluded and all mining and hydrocarbons activities were banned from moorland ecosystems ${ }^{97}$, included $50.73 \%$ of the area of the concession contract 3452 subscribed with ECO ORO.

Following the decision of the Constitutional Court, the Colombian government (through the National Mining Agency, entitled of the administration of mining titles) decided to exclude from the concession contract 3452 all the areas that were considered part of the moorland of Santurban and were, therefore, banned for the development of mining exploration and exploitation activities ${ }^{98}$.

According to ECO ORO, the Angostura project cannot be developed after the decision of the Colombian government and the Country's Constitutional Court ${ }^{99}$. The Company stated that:

"Eco Oro's rights are faced with the threat of further encroachments given the risk that the Constitutional Court and National Mining Agency will issue future decisions further reducing the area accessible to Eco Oro. As a consequence of these uncertainties, the Project cannot currently be licensed. The result of Colombia's measures is that resources remaining in Concession 3452 that could potentially be accessed are insufficient to justify the significant investments required to develop an underground mine. The Project has been rendered unviable"100.

The continuation of the project was also affected by some criticisms made to the role of IFC's participation. The office of the Compliance Advisor Ombudsman for the International Finance Corporation \& Multilateral Investment Guarantee Agency Members of the World Bank Group ('CAO') conducted an investigation of the IFC investment in the Company ECO ORO, particularly about the application of IFC's Sustainability Framework which includes its Policy on Social and Environmental Sustainability (2006 Sustainability Policy) and Performance Standards ${ }^{101}$.

96 Ibid., par. 1.

97 Corte Constitucional [Colombia Constitutional Court], above n 91.

98 MARCO VelásquEZ-Ruiz, La increíble bistoria de la demanda de Eco Oro Minerals contra Colombia [The incredible story of the claim of Eco Oro Minerals against Colombia] El Tiempo (15 December 2016)<http://blogs. eltiempo.com/desmarcado/2016/12/15/la-increible-historia-eco-oro/>

99 Eco Oro Minerals Corp, Colombian National Mining Agency Deprives Eco Oro of its Mining Rigbts (11 August 2016) <http://www.eco-oro.com/s/NewsReleases.asp?ReportID=760306\&_Type=News-Releases\&_ Title $=$ Colombian-National-Mining-Agency-Deprives-Eco-Oro-of-its-Mining-Rights $>$

100 Eco Oro Minerals Corp, above n 82.

101 CAO, above n 84 . 
The Office of the Ombudsman found that "IFC's appraisal and supervision documentation did not promptly capture regulatory actions relevant to IFC's assessment of client capacity and commitment" 102 , that "IFC supervision documentation does not show substantive progress on the completion of necessary studies, such as an adequate biodiversity baseline study or critical habitat assessment"103, and also that "IFC was aware of the project's proximity to the páramo at the time of IFC's investment, and identified this as a risk at appraisal as there was potential for the mine to impact the páramo" 104 .

After a number of criticisms derived from the decision of the Colombian Constitutional Court and the National Mining Agency, and the conclusions of the report of the Ombudsman ${ }^{105}$, the IFC decided to withdraw their support to the project and proceeded to remove their equity investments in the Company ${ }^{106}$. ECO ORO is currently conducting a divestment process.

\section{Viability of the investor's claim}

In December 2016, the Company filed a request for the institution of arbitration proceedings before the International Centre for Settlement of Investment Disputes ('ICSID') for the alleged breach of BITs and free trade agreements between Canada and Colombia ${ }^{107}$.

In its request for arbitration, the Company argues that the Colombian state breached the stipulations of the Free Trade Agreement subscribed with Canada by reducing the area of the mining concession contract as a consequence of the ruling of the Constitutional Court about mining activities in moorland ecosystems.

Claiming to be a protected investor under the Canada-Colombia Free Trade Agreement, the Company believes that the Colombian state failed to provide fair and equitable treatment "through arbitrary, inconsistent and disproportionate measures" ${ }^{\prime \prime} 108$, resulting in a frustration of its legitimate expectations ${ }^{109}$. The Company also argues that the regulatory action of the Colombian state represents an unlawful expropriation of the Company's investment, since the reduction of the accessible area of the mining title destroyed the value of the investment. The Company concludes that the Colombian government failed to provide prompt, adequate and effective compensation ${ }^{110}$.

The Company considers that:

102 Ibid.

103 Ibid.

104 Ibid.

105 CiEL, above n 83.

106 Mining Watch Canada, World Bank Divests from Eco Oro Minerals and Mining in Colombian Páramos (20 December 2016) <http://miningwatch.ca/news/2016/12/20/world-bank-divests-eco-oro-minerals-and-miningcolombian-p-ramos>

107 Eco Oro Minerals Corp. v. Republic of Colombia (ICSID Case n. ${ }^{\circ}$ ARB/16/41)

108 Eco Oro Minerals Corp, above n 82.

109 Ibid.

110 Ibid. 
"Colombia's measures have not only deprived Eco Oro of its investment but also the returns that would have resulted from the Company's investment of hundreds of millions of dollars over the past two decades in reliance upon Colombia's commitments. Eco Oro is therefore asserting its entitlement to recover the losses to its investment resulting from Colombia's breaches. The amount of such losses will be determined at a later stage in the Arbitration" ${ }^{\prime 11}$.

The arbitration is still at an early stage. The acting Secretary-General of the ICSID registered the request for the institution of arbitration proceedings on 29 December 2016. The Tribunal has not yet been constituted ${ }^{112}$.

Is the claim of ECO ORO against the Colombian state viable? Was the reduction of the workable area of the mining title an expropriating decision subject to prompt, adequate and effective compensation?

As we have discussed along this paper, the answer to those questions depends on the analysis of whether the regulatory action undertaken by the Colombian government as a consequence of a judicial ruling should be considered or not an expropriation subject to compensation under the Canada-Colombia Free Trade Agreement.

The complexity of the issue is the commented tension between environmental regulation and the protection of investors' rights in international investment law ${ }^{113}$. According to the specialised literature, "environmental expropriation, or expropriation proceedings based on environmental regulations, has traditionally formed part of the claims for compensation raised in investor-state disputes" ${ }^{\prime 114}$.

A distinctive feature of this tension is the changeability of environmental regulations. The release of new environmental regulations by a host nation may change the legal and financial framework under which an investment was initially made, consequently affecting the future viability of the investors' venture in terms of maintaining the value of the invested assets ${ }^{115}$.

Upcoming environmental regulations that affect foreign investors' proprietary rights have been traditionally considered as cases of compensable indirect expropriation ${ }^{116}$. Regarding the approach of arbitrators to the assessment of the rightfulness of an environmental regulation, international investment law doctrine has traditionally called for a detailed analysis of the reasonability of the governmental action in terms of the

111 Ibid

112 International Centre for Settlement of Investment Disputes ('ICSID'), Case Details Eco Oro Minerals Corp. v. Republic of Colombia (ICSID Case n. ${ }^{\circ}$ ARB/16/41) <https://icsid.worldbank.org/en/Pages/cases/casedetail. aspx? CaseNo=ARB $/ 16 / 41>$

113 Treves, Seatzu and Trevisanut (eds), above n 5, 224.

114 Ibid., 222.

115 Ibid., 225.

116 'As stated in the previously mentioned Santa Elena award, all measures that constitute an expropriation - including those based on reasons of environmental protection - lead to an obligation upon the expropriating state to pay compensation to the expropriated investor. Customary international law does not exclude compensation when an expropriation is based on public purpose, is not arbitrary or discriminatory and respects the principles of due process.' Ibid., 225. 
strength of the scientific grounds that justified the measure ${ }^{117}$. The scientific authority of an environmental regulation is the cornerstone of the legitimacy of regulatory actions when measured against the protection of foreign investors' rights.

Once the validity of the scientific grounds of the decision has been settled, compliance with non-arbitrary, non-discrimination, due process and compensation principles is verified in order to conclude if the regulatory action was lawfully conducted and compensated as an indirect expropriation:

"The main concern of arbitral tribunals should be on whether the measure taken by the host state is one based on an actual concern for the protection of the environment (public purpose). Once this requirement is satisfied, the non-arbitrary and non-discriminatory nature of the measure, the respect of due process and the payment of compensation become to some extent secondary aspects. As long as compensation was paid, the investor was involved in the proceedings and the measure is neither arbitrary nor discriminatory, the action of the state must be considered legal under international law"118.

This tradition has radically changed in recent years given a new set of provisions related to the expropriating nature of environmental regulations that is being included in most of the BITs -inspired by the 2004 and 2012 us Model BITs-. As explained in the first section of this paper, Annex B to the US Model BITs encloses the following provision: "except in rare circumstances, non-discriminatory regulatory actions by a Party that are designed and applied to protect legitimate public welfare objectives, such as public health, safety, and the environment, do not constitute indirect expropriations"119.

This vanguard provision represents a shift in traditional rules on expropriation. It entails that an environmental regulatory measure taken by a host state that affects proprietary rights of a foreign investor shall not be considered an indirect expropriation -and therefore should not be compensated-when is designed and applied by the government to protect legitimate public welfare objectives related to environmental conservation, provided that the regulatory action is based on a non-discriminatory basis ${ }^{120}$.

The applicable Free Trade Agreement to the case under our examination contains an exclusion provision such as the one described above. Annex 811 of the investment chapter of the Canada-Colombia Free Trade Agreement (applicable to the claim raised

117 'an arbitral tribunal considering an expropriation claim arising out of a purported environmental measure should limit its inquiry to determining whether the science underlying the risk determination has the minimal attributes of scientific inquiry - that is, whether the evidence of risk has been derived through the application of legitimate scientific methods and procedures, and is probative of a potential for adverse effects. [...] Once an arbitral tribunal has confirmed that the evidence is scientific and probative, it should accept the legitimate environmental basis for the measure.' J. MARTIN WAGNER, 'International Investment, Expropriation and Environmental Protection' (1999) 29 Golden Gate U. L. Rev., 465, 534.

118 Treves, SeAtzu and Trevisanut (eds.), above n 5, 224.

119 Office of the United States Trade Representative, above n 20.

120 Treves, Seatzu and Trevisanut (eds.), above n 5, 225. 
by ECO ORO) includes the following provision regarding the interpretation of indirect expropriations under the agreement:

"The Parties confirm their shared understanding that:

$(\ldots)$

(b) Except in rare circumstances, such as when a measure or series of measures is so severe in the light of its purpose that it cannot be reasonably viewed as having been adopted in good faith, non-discriminatory measures by a Party that are designed and applied to protect legitimate public welfare objectives, for example health, safety and the protection of the environment, do not constitute indirect expropriation"121.

The applicable provision of the agreement establishes that an environmental regulatory action taken by any of the participant states does not constitute indirect expropriation (and thus is no subject to compensation) provided that the governmental action was non-discriminatory and intended to protect legitimate welfare objectives related to the environment.

The provision goes further and determines that the rare circumstances that will exclude the application of this exception are related to the reasonableness, severity and good faith inspiration of the relevant regulatory measure. This means that a certain regulatory action purportedly conducted to protect a legitimate public welfare objective (such as the environment) shall not be excluded from the general rules of indirect expropriation whenever it can be reasonably considered as unproportioned and unfair.

The provision described above sets the benchmark for the assessment of the viability of the claim of ECO ORO against the Colombian state. The regulatory action taken by the government entailed the restriction of roughly $50 \%$ of the area of the mining title held by the Company. The governmental measure was the consequence of a judicial ruling that reinforced the protection of moorland ecosystems established in the Law 1753 of 2015 by determining that no mining activities were acceptable in areas belonging to those environments. The ruling of the Colombian Constitutional court was based on several scientific evidence about the fragility, sensibility and vulnerability of moorland ecosystems and about the potential harm of the development of mining activities within them.

The action of the Colombian government was, therefore, a non-discriminatory measure applied to protect the Santurban moorland ecosystem as a legitimate public welfare objective. The measure taken by the Colombian government can be considered as proportional and adopted in good faith, taking into account that only the area located within the official delimitation of the moorland was subject to exclusion of the mining title, leaving approximately $50 \%$ of the total area of the title suitable for the development of mining activities by the holder. 
These observations allow us to conclude that the decision of the Colombian government shall not be considered a case of compensable indirect expropriation following the provisions of Annex 811 of the investment chapter of the Canada-Colombia Free Trade Agreement.

\section{CONCLUSIONS}

In the first section of this research paper we discussed the nature of IIA's as an instrument used by states to attract foreign investments within their borders and obtain favourable treatment to local investors in counterpart nations. We also examined how states compromise a certain degree of sovereignty in this kind of agreements through the inclusion of legal stability agreements, stabilisation clauses, compensation for expropriation, and fair \& equitable treatment provisions. The purpose of these sort of stipulations is to reduce political risk by restricting the scope of the states' regulatory powers.

The research conducted in the first section of this paper showed that the legitimate exercise of regulatory powers within IIA's enters in conflict with the protection of foreign investors property rights when it comes to sensitive areas that have a high impact in the public interest, politics and public perception. These sensitive areas include human rights, health, safety, labour standards and the environment.

The conflict is represented in the scope and extent of the notion of indirect expropriation. Even though the indeterminacy and lack of clarity of the concept makes it difficult to solve the tension between the legitimate exercise of regulatory powers and foreign investments protection, we could find some helpful principles (developed from international customary law, benchmark model agreements and arbitral decisions) that contribute to define when a regulatory action should be considered expropriating, and therefore subject to fair and equitable compensation.

Given the fact that the application of such principles requires the analysis of the circumstances of particular cases, in the second section of this research paper we conducted the discussion of two recent paramount cases that involve regulatory actions of the Colombian state and property rights of foreign investors. Both cases were related to those sensitive areas of high tension between government action and investors' rights: pharmaceutical IP rights vs public health interests in the first case, consolidated mining titles vs environmental protection in the second case.

The examination of these cases showed us the difficulties when defining if a governmental regulatory action is legitimate and non-compensable or if it is subject to compensation as an indirect expropriation. It also demonstrated that the nature of this kind of disputes makes them highly contingent and fundamentally dependent on the interpretation of arbitral tribunals.

By applying the criteria presented in the first section of the paper, and the relevant provisions of applicable IIAs and BITs, we were able to conclude that the claims of foreign investors against the Colombian state are not viable. We observed that in both cases 
the government's actions can be considered a non-compensable legitimate exercise of regulatory powers under the applicable agreements.

Our research showed how the recommendation contained in Annex B to the US Model BITs - which provides that a regulatory action of a host nation should not be considered as an indirect expropriation when it is adopted on a non-discriminatory basis and is intended to protect public interest objectives (e.g. health or the environment)- has been adopted in a fair amount of the most recent BITs worldwide, including the investment chapter of the Canada-Colombia Free Trade Agreement.

As shown by our case analysis, this provision represents a major threat for foreign investors since it entails an exception to the general rules of expropriation applicable in case of deprivation of investors' proprietary rights as a consequence of governmental regulations. The cases of Novartis and ECO ORO demonstrate how such provision shifts political risk towards investors when it comes to legitimate regulations adopted to protect public health or the environment.

The recommendation that follows the findings of our research is that investors should pay specific attention to the existence of this kind of clauses during the assessment of political risk in the host country, and provide efficient mechanisms (e.g. insurances, government agreements, etc.) that help mitigate the financial impact of such risk in the future.

\section{BIBLIOGRAPHY}

\section{A. Books}

Grosse Ruse-Kahn, Henning, Protection of intellectual property in international law (Oxford: Oxford University Press, 2016).

HARMS, PHILLIP, International Investment Political Risk and Growth (New York: Springer, 2000).

TITI, AIKATERINI, The right to regulate in international investment law (Baden-Baden: Nomos, 2014).

Treves, Tullio, Francesco Seatzu, and Seline Trevisanut (eds.), Foreign investment international law and common concerns (Abingdon, Oxon: Routledge, 2014).

Yannaca-Small, Katia, Arbitration under international investment agreements: a guide to key issues (Oxford: OUP, 2010).

\section{B. Journal Articles}

Howell, Lewellyn and Brad Chaddick, 'Models of Political Risk for Foreign Investment and Trade An Assessment of Three Approaches' (1994) 29 Columbia Journal of World Business 70. WAGNER, J. MARTIN, 'International Investment, Expropriation and Environmental Protection' (1999) 29 Golden Gate U. L. Rev., 465.

\section{International Agreements}


Agreement on Trade-Related Aspects of Intellectual Property Rights (TRIPS), Annex 1C of the World Trade Agreement (Marrakesh, 15 April 1994, 1869 UNTS 299).

Free Trade Agreement between the Republic of Colombia and The EFTA States.

Canada-Colombia Free Trade Agreement.

\section{Internet Materials}

Center for International Environmental Law ('CIEL'), World Bank divests from Eco Oro Minerals and its mining project in the Colombian Páramos (21 December 2016) <http://www.ciel.org/news/9504/>

Eco Oro Minerals Corp, Eco Oro files Request for Arbitration against Colombia (09 December 2016) <http:// www.eco-oro.com/s/NewsReleases.asp?ReportID=774271\&_Type=News-Releases\&_Title=EcoOro-files-Request-for-Arbitration-against-Colombia >

Eco Oro Minerals Corp, Colombian National Mining Agency Deprives Eco Oro of its Mining Rights $(11$ August 2016) <http://www.eco-oro.com/s/NewsReleases.asp?ReportID=760306\&_Type=News-Releases\&_Title=Colombian-National-Mining-Agency-Deprives-Eco-Oro-of-its-Mining-Rights $>$

El Espectador, Las presiones de EE.UU. para que Colombia no regule el precio del imatinib [The pressures of the United States to prevent the Colombian price regulation of imatinib] (10 May 2016) <http:// www.elespectador.com/noticias/salud/presiones-de-eeuu-colombia-no-regule-el-precio-delimat-articulo-631535>

El Tiempo, Minambiente delimita 98.954 bectáreas, el $76 \%$ del páramo de Santurbán [The Ministry of Environment delimitates 98.954 hectares, $76 \%$ of the Santurban moorland] (19 December 2014) <http://www.eltiempo.com/colombia/otras-ciudades/delimitacion-del-paramo-desanturban/14996735>

Environmental Justice Organisations Liabilities and Trade ('EJOLT'), The Angostura Mining Project in the Paramo of Santurban, Colombia (25 February 2013) < http://www.ejolt.org/wordpress/wp-content/ uploads/2013/02/FS_002_Angostura.pdf>

Interamerican Association for Environmental Defense ('AIDA'), Protecting the Santurban Páramo from Angostura Mining Project <http://www.aida-americas.org/protecting_the_santurban_paramo_ from_angostura_project $>$

International Centre for Settlement of Investment Disputes ('ICSID'), Case Details Eco Oro Minerals Corp. v. Republic of Colombia (ICSID Case n. ${ }^{\circ}$ ARB/16/41) < https://icsid.worldbank.org/en/Pages/ cases/casedetail.aspx? CaseNo=ARB/16/41>

Italaw, Canada 2003 Model BIT <http://www.italaw.com/documents/Canadian2004-FIPA-model-en.pdf> Mazin Sidahmed, Climate change denial in the Trump cabinet: where do bis nominees stand? The Guardian (16 December 2016) <https://www.theguardian.com/environment/2016/dec/15/trump-cabinetclimate-change-deniers $>$

Mining Journal, Eco Oro requests arbitration (15 December 2016) <http://www.mining-journal.com/ world/centralsouth-america/eco-oro-requests-arbitration/>

Mining Watch Canada, World Bank Divests from Eco Oro Minerals and Mining in Colombian Páramos (20 December 2016) <http://miningwatch.ca/news/2016/12/20/world-bank-divests-eco-orominerals-and-mining-colombian-p-ramos> 
Ministry of Commerce, Industry and Tourism of the Republic of Colombia, Acuerdos Comerciales $y$ de Inversión [Commercial and Investment Agreements] <http://www.tlc.gov.co/index.php>

Ministry of Commerce, Industry and Tourism of the Republic of Colombia, Acuerdos Internacionales de Inversión Suscritos [Subscribed International Investment Agreements] <http://www.tlc.gov. co/publicaciones. . php?id $=6421>$

Ministry of Commerce, Industry and Tourism of the Republic of Colombia, Acuerdos Internacionales de Inversión Vigentes [Effective International Investment Agreements] <http://www.tlc.gov.co/ publicaciones. php?id $=6420>$

Ministry of Commerce, Industry and Tourism of the Republic of Colombia, Acuerdos Vigentes [Effective Agreements] <http://www.tlc.gov.co/publicaciones.php?id=5398>

Ministry of Commerce, Industry and Tourism of the Republic of Colombia, Acuerdos Internacionales de Inversión [International Investment Agreements] <http://www.tlc.gov.co/publicaciones. php?id=6126>

Ministry of Health and Social Protection of the Republic of Colombia, Special request for declaring the existence of reasons of public interest over the medicine imatinib < https://www.minsalud.gov.co/sites/ rid/Lists/BibliotecaDigital/RIDE/VS/MET/Solicitud-de-una-declaracion-en-el-acceso-al-medicamento-IMATINIB.pdf>

Ministry of Health and Social Protection of the Republic of Colombia, Análisis de mercado del imatinib en colombia y proyección de impacto presupuestal de la declaratoria de razones de interés público [Market analysis of imatinib in Colombia and projection of the budgetary impact of the declaration of reasons of public interest] <https://www.minsalud.gov.co/salud/MT/Paginas/medicamentospropiedad-intelectual.aspx>

Ministry of Health and Social Protection of the Republic of Colombia, El Gobierno fija el precio del Glivec en \$206 por miligramo [Government fixes the price of Glivec at COP\$206 per milligram] $<$ https://www.minsalud.gov.co/Paginas/El-Gobierno-fija-el-precio-del-Glivec-en-\$-206-pormiligramo.aspx>

Ministry of Health and Social Protection of the Republic of Colombia, Resolution 2475 of 14 June $2016<$ https://www.minsalud.gov.co/sites/rid/Lists/BibliotecaDigital/RIDE/DE/DIJ/Resolucion2475-de-2016.pdf>

Novartis, Que es Glivec? [What is Glivec] <http://www.novartis.com.co/prensa/glivec.shtml>

Office of the Compliance Advisor Ombudsman for the International Finance Corporation \& Multilateral Investment Guarantee Agency Members of the World Bank Group ('CAO'), CAO Investigation of IFC Investment in: Eco Oro Minerals Corporation Limited (\#27961) <http://www.caoombudsman.org/cases/document-links/documents/CAOComplianceInvestigationReportonIFCinvestmentinEcoOroMinerals-English.pdf>

Office of the United States Trade Representative, US 2012 Model BIT < https://ustr.gov/sites/default/ files/BIT\%20text\%20for\%20ACIEP\%20Meeting.pdf>

The World Bank, Overview (26 September 2016) The World Bank <http://www.worldbank.org/ en/country/colombia/overview\#1 >

United Nations Framework Convention on Climate Change, Summary of the Paris Agreement $<\mathrm{http}: / /$ bigpicture.unfccc.int/\#content-the-paris-agreemen> 
United Nations Framework Convention on Climate Change, Marrakecb Climate Change Conference November $2016<$ http://unfccc.int/meetings/marrakech_nov_2016/meeting/9567.php>

United Nations Framework Convention on Climate Change, Kyoto Protocol <http://unfccc.int/ kyoto_protocol/items/2830.php>

VelásqueZ-Ruiz, Marco, La increíble bistoria de la demanda de Eco Oro Minerals contra Colombia [The incredible story of the claim of Eco Oro Minerals against Colombia] El Tiempo (15 December 2016) <http://blogs.eltiempo.com/desmarcado/2016/12/15/la-increible-historia-eco-oro/>

World Health Organization, Who we are what we do <http://www.who.int/about/en/>

World Health Organization, WHO Model Lists of Essential Medicines < http://www.who.int/medicines/ publications/essentialmedicines/en/>

World Trade Organization, Intellectual property: protection and enforcement <https://www.wto.org/english/ thewto_e/whatis_e/tif_e/agrm7_e.htm>

\section{E. Reports}

Klaus Schwab and Xavier Sala-i-Martín, 'The Global Competitiveness Report 2016-2017' (Report, World Economic Forum, 2016).

PricewaterhouseCoopers, Pharma 2020: Challenging business models Which path will you take? (Report, PricewaterhouseCoopers, 2009).

\section{F. Legislation}

Constitución Política de Colombia 1991 [Colombian Constitution 1991].

Ley 1751 de 2015 [Law 1751 of 2015].

\section{G. Judicial decisions}

Corte Constitucional [Colombian Constitutional Court], C-035, 8 February 2016.

\section{H. Arbitrations}

Eco Oro Minerals Corp. v. Republic of Colombia (ICSID Case n. ${ }^{\circ}$ ARB/16/41). 